\title{
Population dynamics of Chrysichthys nigrodigitatus (Lacépède, 1803) in Ikere-gorge, Oyo State, Nigeria
}

\author{
S.O.AJAGBE*,D.O.ODULATE, R.O.AJAGBE, O.S.ARIWOOLA, F.I.ABDULAZEEZ, \\ O.O. OYEWOLE, M.T.OJUBOLAMO, I.O.ARABAMBI, I.E. ODIAKA, B.O. FADIMU,
} A.O. OLOMOLA, O.A. GANIYU \& O.O. OYEKAN

(S.O.A, F.I.A, M.T.O, I.O.A, I.E.O, B.O.F, A.O.O, O.A.G \& O.O.O.: Department of Aquaculture and Fisheries Management, Federal University of Agriculture, Abeokuta, P.M.B. 2240, Abeokuta, Nigeria; D.O.O.: Department of Wildlife and Ecotourism, Forestry Research Institute of Nigeria, P.M.B. 5054, Jericho, Ibadan, Nigeria; R.O.A.: Department of Forest Economics and Extension, Forestry Research Institute of Nigeria, P.M.B. 5054, Jericho, Ibadan, Nigeria; O.S.A \& O.O.O.: Federal College of Forestry, Jericho, Ibadan, Nigeria) *Corresponding author's email: stephenolua@gmail.com; ORID: https://orcid.org/00000003-3760-0627

\begin{abstract}
The growth and mortality parameters of Chrysichthys nigrodigitatus were estimated to assess the sustainability of its exploitation in Ikere-gorge, Oyo State, Nigeria. A total of 1210 of Chrysichthys nigrodigitatus were sampled from fishermen catches between January, 2017 and December, 2018. C. nigrodigitatus were exploited with gillnet, cast net and traps (Malian trap net and bamboo). Total lengths were measured with fish measuring board. The FAO-ICLARM Stock Assessment Tool (FiSAT II) software was used to analyze length-frequency data of the fish. The estimated growth parameters are: asymptotic length is $60.9 \mathrm{~cm}$, growth coefficient is 0.96 , optimum length is $38.51 \mathrm{~cm}$; length at maturity is $33.44 \mathrm{~cm}$ while length-at-first-capture is 12.62 $\mathrm{cm}$. The estimated mortality parameters are: total mortality is 3.29 per year, natural mortality is 1.43 per year and fishing mortality is 1.86 . It was observed that $C$. nigrodigitatus of Ikere-gorge were more vulnerable to exploitation at sizes less than their length at maturity. Likewise, the exploitation rate $\left(\mathrm{E}=0.57 \mathrm{yr}^{-1}\right)$ is greater than sustainable exploitation rate $\left(\mathrm{E}_{\max }=0.46 \mathrm{yr}^{-1}\right)$. This shows that exploitation of $C$. nigrodigitatus in Ikere-gorge is not sustainable. Therefore, there is need to reduce fishing pressure on C. nigrodigitatus to ensure its sustainability in Ikere-gorge.
\end{abstract}

Keywords: Exploitation; Fish species; Growth performance; Recruitment; Sustainable Original scientific paper. Received 20 May 2020; revised 03 Feb 2021

\section{Introduction}

Fish population is a group of the same species or subspecies of fish that are spatially and genetically separated from other groups (Pope et al., 2010). Fish population dynamics is the study of continuous changing of fish stock with time due to factors such as reproduction (recruitment), mortality, migration (immigration and emigration), growth and yield. The objective of studying fish population dynamics is to ensure rational management and conservation of fishery resources (Udoh et al., 2015).

Ghana Jnl Agric. Sci. 56 (1), 79 - 86

GJAS is an Open Access Journal and distributed under the terms of the Creative Commons (CC) License [CC BY 4.0] 
Fish stock is a sub-set of one fish species having the same growth and mortality parameters and inhabiting a particular geographical area (Ajang et al., 2013). Stock is a fundamental concept to fish population dynamics. The most important task is to estimate population parameters (i.e. growth, recruitment, mortality and migration) of a specific fish or a group of fish species. Among these four variables, Pope et al. (2010) reviewed that annual recruitment is typically the most variable factor affecting the dynamics of fish populations but it can provide substantial insight into why fish populations may vary in size and structure.

Chrysichthys nigrodigitatus is an important ecological and commercial fish species in tropical freshwater ecosystems (Ikongbeh et al., 2015). This fish is abundant in Ikere-gorge and it occurs in every catch of fishermen. However, smaller sizes and juveniles are predominant in their catches, an indication of growth overfishing threat to the fisheries. The fishermen of Ikere-gorge employ different types of fishing gears to exploit $C$. nigrodigitatus. These gears include gillnets of various mesh sizes, cast nets, bamboo traps (Kolombo), Malian traps (Gura), wire nets and hooks. This study aimed to assess the growth and mortality parameters of $C$. nigrodigitatus of Ikere-gorge so as to provide useful information on the management of the fish in the gorge.

\section{Materials and Methods}

\section{Study area}

Ikere-gorge is located between longitude $8^{\circ} 10^{\prime}$ and $8^{\circ} 20^{\prime} \mathrm{N}$ and latitude $3^{\circ} 40^{\prime}$ and $3^{\circ} 50^{\prime} \mathrm{E}$ (Figure 1). Ikere-gorge is a 565 million cubic metres multipurpose dam located at Ikere village, about $28 \mathrm{~km}$, North East of Iseyin in Oyo State. The southern parts of the dam are characterised with rocky hills and valley. The water bed comprises mainly of fine and coarse sand particles and gravels.

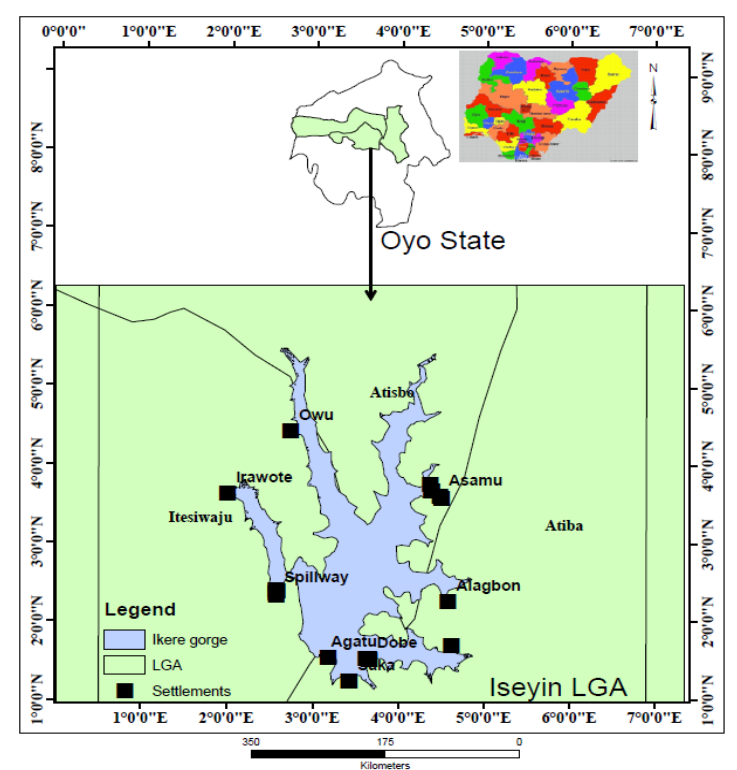

Fig. 1: Map of Ikere-gorge (showing some fishing villages), Oyo State, Nigeria 


\section{Fish sampling}

The fishermen of Ikere-gorge exploit $C . n i-$ grodigitatus with different types of fishing gears such as gillnets, cast nets, bamboo traps (Kolombo), Malian traps (Gura) and wire nets. A total 1210 of C. nigrodigitatus was sampled from the catches of commercial fishermen between 8 am and 12 noon from January, 2017 to December, 2018. The fish was identified with keys provided by Olaosebikan and Raji (2013). The total length of the fish was measured with a fish measuring board to the nearest centimetre $(\mathrm{cm})$

Estimation of growth and mortality parameters The means of the two years (2017 and 2018) monthly length-frequency distribution of $C$. nigrodigitatus were pooled together as annual data. They were analyzed using the procedure of Gayanilo Jr. et al. (2005) of the FiSAT II (version 1.2.2) computer software package of fish stock assessment. ELEFAN I (nonparametric scoring of von Bertalanffy Growth Function VBGF Fit) and II subroutines of the software were used to estimate von Bertalanffy growth and mortality parameters, recruitment patterns and probability of capture. The equation for growth in length is given by,

$L_{t}=L_{\infty}\left[1-\exp \left\{-K\left(t-t_{0}\right)\right\}\right]$

Where: $L_{t}$ is the estimated length at age $\mathrm{t} ; L_{\infty}$ is the asymptotic length in $\mathrm{cm}$; $K$ is a growth coefficient; ' $\boldsymbol{t}_{0}$ ' is the theoretical age at which fish would have had zero length (Pauly 1986; Abdul et al. 2012).

The overall growth performances index $\left(\varnothing^{\prime}\right)$ for the selected fish species were computed using the Pauly and Munro (1984):

$\varnothing^{\prime}=\log 10 K+2 \log 10 L_{\infty}$

Natural mortality was estimated using Pauly (1980) $\ln M=-0.0152-0.279 \ln L_{\infty}+0.06543 \ln K+$ $0.4634 \ln \check{T}$

Where: $M$ is the natural mortality; $\check{T}$ was $28.14^{\circ} \mathrm{C}$, the annual mean surface water temperature of Ikere gorge.

The total mortality, $Z$, was obtained according to the model proposed by Ssentongo and Larkin (1973):

$Z=\left(n K /(n+1)\left(\ln \left(L_{\infty}-L_{c}\right)\left(L_{\infty}-\dot{L}\right)\right)^{-1}\right.$

Where: $n$ is the number of fishes sampled; $L$ is the length of the smallest fish in the sample; $L$ is the average length in the samples

But, total fishing mortality is:

$$
Z=F+M
$$

Therefore, fishing mortality $(F)$ can be estimated as:

$$
F=Z-M
$$

Therefore, exploitation rate $(E)$ which is the mortality rate due to fishing activities can be estimated as:

$$
E=F / F+M=F / Z
$$

Length-at-first-maturity, $\mathrm{L}$ was estimated as:

$\log L_{m}=0.8776 \log L_{\infty}-0.38$

Longevity was obtained from the following equation (Pauly 1983):

$$
t_{\max }=t_{0}+3 / K
$$

Where: $t_{\max }$ is the approximate maximum age the fish of a given population would reach.

\section{Results and Discussion}

The growth and the mortality parameters of Chrysichthys nigrodigitatus of Ikere gorge are presented in Table 1. The total number of $C$. nigrodigitatus sampled during the study was 1,210 and the length of the fish varied from 8.0 to $58.0 \mathrm{~cm}$ with a mean of $21.54 \pm 5.83 \mathrm{~cm}$. Table 2 shows the total number of $C$. nigrodigitatus caught, in which corresponding months of each year (the years 2017 and 2018) were added to make data for the month. However, Famoofo and Abdul (2020) reported that the 
length of $C$. nigrodigitatus in Iwopin freshwater ecotype of Lekki Lagoon, Ogun State, Southwest Nigeria ranged from 12.2 to $34.8 \mathrm{~cm}$ with a mean of $27.2 \pm 1.0 \mathrm{~cm}$.

Figure 2 shows the von Bertalanffy growth curves for $C$. nigrodigitatus. The asymptotic length or the theoretical maximum length $\left(\mathrm{L}_{\infty}\right)$ for which C. nigrodigitatus of Ikere gorge would reach if it lived indefinitely was $60.90 \mathrm{~cm}$. There is a simple relationship between maximum length and asymptotic length in which the latter is about 5.0\% longer than the former (Froese \& Binohlan, 2000). The value of $L_{\infty}, 60.90 \mathrm{~cm}$ observed in this study was lower than the value $(98.25 \mathrm{~cm})$ reported by Ajang et al. (2013) in the lower reaches of the Cross River Estuary, Nigeria. But the asymptotic length $\left(\mathrm{L}_{\infty}\right)$ of $C$. nigrodigitatus of Ikere gorge was greater than $44.5 \mathrm{~cm}$ reported by Ofori-Danson et al. (2002) for C. nigrodigitatus in Lake Volta, Ghana. It is also greater than $29.93 \mathrm{~cm}$ reported by Uneke (2018) for C. nigrodigitatus in the Mid Cross River Flood System, South Eastern Nigeria and $37.28 \mathrm{~cm}$ reported by Ikongbeh et al. (2015) for C. nigrodigitatus from Lake Akata, Benue State, Nigeria.

The growth coefficient $(K)$ of $C . n i$ grodigitatus of Ikere gorge was $0.96 /$ year. This is the rate at which $C$. nigrodigitatus would attain its maximum length in Ikere-gorge. This value is consistent with the result of Ajang et al. (2013) for C. nigrodigitatus in lower reaches of the Cross River Estuary, Nigeria. However, Ofori-Danson et al. (2002) reported $K$-value of $0.65 /$ year for $C$. nigrodigitatus in Lake Volta, Ghana. Likewise, the growth performance $\left(\varnothing^{\prime}\right)$ of $C$. nigrodigitatus of Ikere gorge was 3.55 while its longevity was 3.13 years. There is an inverse relationship between $K$-value and longevity of a fish; as the $K$-value increases, the longevity decreases and vice versa (Sparre $\&$ Venema, 1998). The $K$-value, longevity and growth performance of $C$. nigrodigitatus obtained in this study were in agreement with the findings of Abdul et al. (2009), who reported $K$-value, longevity and growth performance of 0.98 year, 3.06 years and 3.66 respectively for C. nigrodigitatus in Iwopin area of Lekki Lagoon, Ogun State.

Length at first capture or $50 \%$ of the stock $\left(L_{50}\right)$ being vulnerable to fishing gear was $12.62 \mathrm{~cm}$. The length at first maturity $\left(L_{m}\right)$ of C. nigrodigitatus was $33.44 \mathrm{~cm}$ while the optimum length $\left(L_{o p t}\right)$ which is the length at which the total biomass of a year-class reaches a maximum value was $38.51 \mathrm{~cm}$. This shows that $C$. nigrodigitatus of Ikere-gorge are vulnerable to exploitation at smaller sizes than their maturity size. Growth overfishing would be avoided if a fish was allowed to reproduce at least once before it becomes vulnerable to exploitation (Kennelly, 2007; King, 2007; Humphries \& Walker, 2013).

The recruitment patterns of $C$. nigrodigitatus in Ikere-gorge shows two recruitment cycles per year (Figure 3) during the period of study (2017 and 2018). The first recruitment occurred from February to June and the peak was in June. The second recruitment period occurred from August to November, and the peak was in October. This observation is in agreement with Pauly (1982) that tropical fish species are short-lived and have double recruitment pulses per year. The recruitment pattern for $C$. nigrodigitatus in Ikere-gorge was consistent with that which was reported for C. auratus in Damietta branch of the River Nile in Egypt (Ragheb, 2016).

The instantaneous rate of total mortality per year $(Z)$ of $C$. nigrodigitatus was 3.29/ year, the natural mortality, $M$ was $1.43 /$ year, the 
fishing mortality, F was 1.86/year and the exploitation rate was $0.57 /$ year, and the average temperature of $28.14^{\circ} \mathrm{C}$ in Ikere-gorge (Figure $4)$. These were lower than the total mortality $(Z)$ of $6.27 /$ year and fishing mortality $(F)$ of $5.05 /$ year reported by Ajang et al. (2013) for C. nigrodigitatus in lower reaches of the Cross River Estuary, Nigeria. Ofori-Danson et al. (2002), reported that mortality rate estimates for $C$. nigrodigitatus in Lake Volta, Ghana were $Z=3.77 /$ year, $M=1.24 /$ year, $\mathrm{F}=2.53 /$ year and exploitation ratio, $E=0.67$. In addition, the difference between the current exploitation rate $(\mathrm{E}$ $=0.57)$ and sustainable exploitation rate $\left(E_{\max }=\right.$ 0.46 ) shows that $C$. nigrodigitatus is one of the most exploited fish in Ikere-gorge and its current rate of exploitation has to be reduced by $23.91 \%$ for the exploitation to be sustainable. This is in agreement with the report of Udoh et al. (2015) in which they suggested $10-40 \%$ reduction in fishing mortality of $C$. nigrodigitatus in Lower Cross River, Nigeria

The virtual population of $C$. nigrodigitatus in Ikere-gorge showed that fishing mortality of the stock was highest between the length range of 18.0 and $28.0 \mathrm{~cm}$. This is the length range of $C$. nigrodigitatus that was heavily exploited in Ikere-gorge. Figure 5 shows that natural mortality (as a result of predation, diseases etc) predominates within the unexploited length range of 6.0 to $10.0 \mathrm{~cm}$ of all $C$. nigrodigitatus mortality. Fishing mortality increased steadily from length $10.0 \mathrm{~cm}$ and it predominated at a length of $18.0 \mathrm{~cm}$. There was full exploitation at sizes $28.0 \mathrm{~cm}$ and above. This suggests that there was growth overfishing of $C$. nigrodigitatus in Ikere-gorge, because most $C$. nigrodigitatus were not allowed to growth and mature enough to reproduce or recruit at least once before capture. The ratio of length-at-first-capture to asymptotic length $\left(L_{c} /\right.$ $\left.L_{\infty}\right)$ was 0.21 . This shows that $C$. nigrodigitatus of Ikere-gorge is vulnerable to gear or capture when it is just $21 \%$ of its asymptotic length. Likewise, the ratio of natural mortality to von Bertalanffy growth coefficient $(M / K)$ was 1.49 . The value of $M / K(1.49)$ obtained in this study was within the range recommended by Berverton and Holt (1966) which was 1.0 to 2.5. This is an indication that growth and mortality parameters obtained in this study are valid for scientific deduction and interpretation. Also, the ratio of total mortality to von Bertalanffy growth coefficient $(Z / K)$ obtained in this work is greater than $1(Z / K>1)$, then it showed that mortality dominate $C$. nigrodigitatus population in Ikere-gorge (Udoh et al., 2015).

TABLE 1

Growth and mortality parameters of Chrysicthys nigrodigitatus (January 2017 to December 2018) in Ikere-gorge, Iseyin, Oyo State, Nigeria

\begin{tabular}{|c|c|}
\hline Parameter & Value \\
\hline Total number of individual fish sampled & 1,210 \\
\hline Maximum length, $\mathrm{L}_{\max }(\mathrm{cm})$ & 58.0 \\
\hline Minimum length, $\mathrm{L}_{\min }^{\max }(\mathrm{cm})$ & 8.0 \\
\hline Asymptotic length, $\mathrm{L}_{\infty}(\mathrm{cm})$ & 60.9 \\
\hline Growth coefficient, K (VBGF) / year & 0.96 \\
\hline Overall growth performance index, $\varnothing^{\prime}$ & 3.55 \\
\hline Optimum length Lopt $(\mathrm{cm})$ & 38.51 \\
\hline Length at maturity, $\mathrm{L}_{\mathrm{m}}(\mathrm{cm})$ & 33.4 \\
\hline Length at first capture, $\mathrm{L}_{50}(\mathrm{~cm})$ & 12.6 \\
\hline Total mortality, $\mathrm{Z},\left(\mathrm{yr}^{-1}\right)$ & 3.29 \\
\hline Natural mortality, $\mathrm{M},\left(\mathrm{yr}^{-1}\right)$ & 1.43 \\
\hline Fishing mortality, $\mathrm{F},\left(\mathrm{yr}^{-1}\right)$ & 1.86 \\
\hline $\mathrm{Z} / \mathrm{K}$ & 3.43 \\
\hline $\mathrm{M} / \mathrm{K}$ & 1.49 \\
\hline Sustainable exploitation $\left(\mathrm{E}_{\mathrm{max}} \mathrm{yr}^{-1}\right)$ & 0.46 \\
\hline Exploitation rate, $\mathrm{E}\left(\mathrm{yr}^{-1}\right)$ & 0.57 \\
\hline $\mathrm{L}_{c} / \mathrm{L}_{\infty}$ & 0.21 \\
\hline Longevity (year) & 3.13 \\
\hline
\end{tabular}

Key: Z/K: ratio of total mortality to von Bertalanffy growth coefficient; $\mathrm{M} / \mathrm{K}$ : the ratio of natural mortality to von Bertalanffy growth coefficient; $\mathrm{L}_{c} / \mathrm{L}_{\infty:}$ the ratio of length-at-first-capture to asymptotic length 
TABLE 2

Monthly data of Chrysichthys nigrodigitatus caught between January 2017 and December 2018 in Ikeregorge, Iseyin, Oyo State, Nigeria

\begin{tabular}{ll} 
Months & $\begin{array}{l}\text { Number of Chrysichthys } \\
\text { nigrodigitatus caught }\end{array}$ \\
\hline January & 125 \\
February & 99 \\
March & 104 \\
April & 130 \\
May & 78 \\
June & 123 \\
July & 163 \\
August & 133 \\
September & 63 \\
October & 97 \\
November & 52 \\
December & 43 \\
\hline Total & 1210 \\
\hline
\end{tabular}

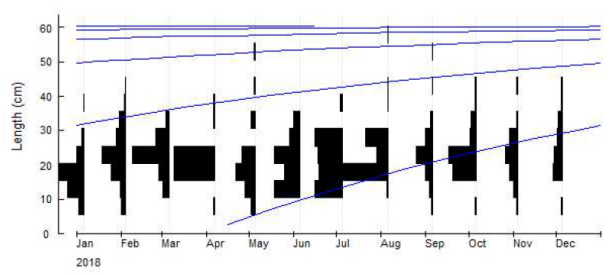

Fig. 2: The von Bertalanffy growth function curves of C. nigrodigitatus (2017 and 2018) in Ikere-gorge, Iseyin, Oyo State, Nigeria (drawn using ELEFAN 1 programme; $\mathrm{L} \infty=60.9 \mathrm{~cm} ; \mathrm{K}=0.96 /$ year)

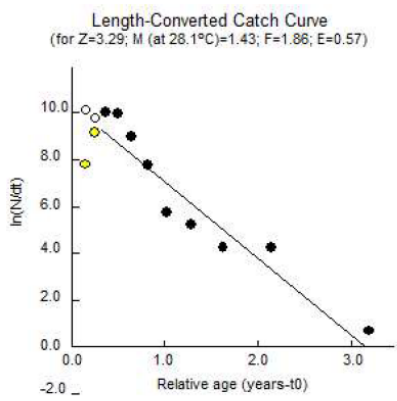

Fig. 3: The recruitment pattern of Chrysicthys nigrodigitatus (2017 and 2018) in Ikere-gorge, Iseyin, Oyo State, Nigeria

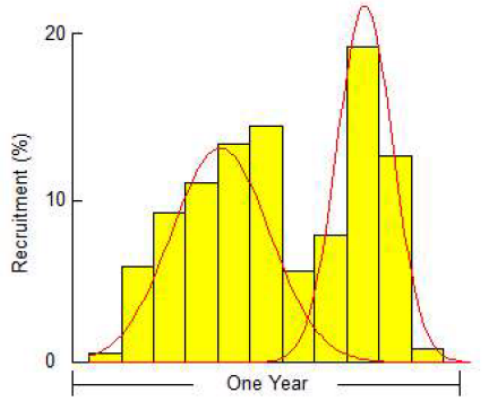

Fig. 4: The length converted catch curve of Chrysicthys nigrodigitatus (2017 and 2018) in Ikere-gorge, Iseyin, Oyo State, Nigeria

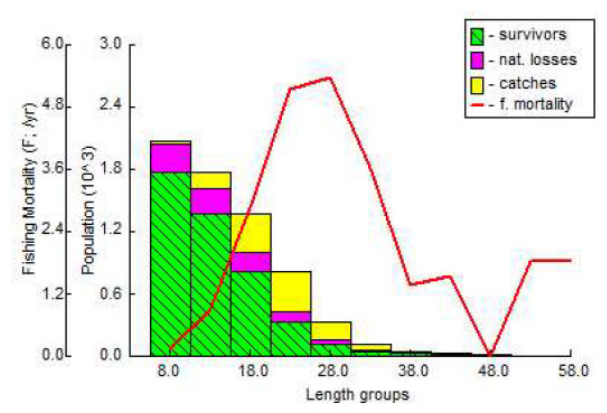

Fig. 5: Virtual population analysis of Chrysichthys nigrodigitatus (2017 and 2018) in Ikere-gorge, Iseyin, Oyo State, Nigeria

\section{Conclusion}

The growth and mortality parameters of $C$. nigrodigitatus of Ikere-gorge, Iseyin, Oyo State, Nigeria were estimated in this study. Result obtained shows that $C$. nigrodigitatus of Ikere-gorge are vulnerable to exploitation at length $\left(\mathrm{L}_{50}=12.6 \mathrm{~cm}\right)$ smaller than their length at maturity $\left(\mathrm{L}_{\mathrm{m}}=33.4 \mathrm{~cm}\right)$. Likewise, the exploitation rate $(\mathrm{E}=0.57)$ is greater than sustainable exploitation rate $\left(\mathrm{E}_{\max }=0.46\right)$. This shows that exploitation of $C$. nigrodigitatus in Ikere-gorge is not sustainable. In order for the exploitation of $C$. nigrodigitatus in Ikere-gorge to be sustainable, the exploitation rate has to be reduced by at least $23.91 \%$ based on the 
difference between the current and sustainable exploitation rates.

\section{Acknowledgement}

The authors wish to acknowledge the support of Idea Wild Biodiversity Conservation Organisation of United States of America for donating the Research equipment for this work.

\section{REFERENCES}

Abdul, W.O, Omoniyi, I.T., Odulate, D.O. \& Olaluwoye, B.L. (2009) Assessment of Chrysichthys nigrodigitatus in Iwopin area of Lekki Lagoon, Ogun State, Nigeria: Empirical Approach. Aquafield 5, $33-42$.

Abdul, W.O., Omoniyi, I.T., Akegbejo-Samsons Y., Akinyemi, A.A, Agbon, A.O. \& Adeosun F.I. (2012) Management indicators and growth performance index of Tilapia zillii in a tropical coastal estuary. Journal of Agricultural Science 41, 66 - 77.

Ajang, R.O., Ndome, C.B., Ekwu, A., Uttah, E.C. \& Iboh, C.I. (2013) Population dynamics and gillnets selectivity of Chrysichthys nigrodigitatus (Lacepede, 1803) in lower reaches of the Cross River Estuary, Nigeria. Ethiopian Journal of Environmental Studies and Management 6, $31-40$.

Beverton, R.J.H. \& Holt, S.J. (1966) Manual of methods for fish stock assessment. Part II. Tables of yield function.' FAO Fisheries Biology Technical Paper 38, 10 - 67.

Famoofo, O.O. \& Abdul W.O. (2020) Biometry, condition factors and length-weight relationships of sixteen fish species in Iwopin fresh-water ecotype of Lekki Lagoon, Ogun State, Southwest Nigeria. Heliyon 6, $1-8$.

Froese, R. \& Binohlan, C. (2000) Empirical relationship to estimate asymptotic length, lengthat-first maturity and length maximum yield per recruit in fishes, with a simple method to evaluate frequency data. Journal of Fish Biology 56, 758 - 773 .
Gayanilo, F.C. Jr, Sparre, P. \& Pauly, D. (2005) FAO-ICLARM Stock Assessment Tools II (FiSAT II). Revised version. User's guide. FAO Computerized Information Series (Fisheries). No. 8, Revised version. Rome, FAO. 2005. p.168. (Includes a CD-ROM with the software).

Humphries, P. \& Walker, K.F. (2013) Ecology of Australian freshwater fishes. CSIRO Publishing, 150 Oxford Street, Australia, p. 472.

Ikongbeh, O.A., Ogbe, F.G., Solomon, S.G. \& Ataguba, G.A. (2015) Age, growth and mortality of Chrysichthyes nigrodigitatus (Lacépède, 1803) from Lake Akata, Benue State, Nigeria, Asian Journal of Conservation Biology 4, $81-88$.

Kennelly, S.J. (2007) By-catch reduction in the World's fisheries. Springer, P. O. Box 17, 3300 AA, Dordrecht, The Netherlands.

King, M.G. (2007) Fisheries biology, assessment and management $/ 2^{\text {nd }}$ Edition, Blackwell Publishing Company, p. 635.

Ofori-Danson, P.K., Graaf, G.J. \& Vanderpuye, C.J. (2002) Population parameter estimates for Chrysichthys auratus and C. nigrodigitatus (Pisces: Claroteidae) in Lake Volta, Ghana. Fisheries Research 54, 267 - 277.

Olaosebikan, B.D. \& Raji A. (2013) Field Guide to Nigerian Freshwater Fishes. Federal College of Freshwater Fisheries Technology, New Bussa, Nigeria, Revised Edition. p.144.

Pauly, D. (1980) On the interrelationships between natural mortality, growth parameters and mean environmental temperature in 175 Fish stocks. Journal of Conservation CIEM 39, $175-192$.

Pauly, D. (1982) Studying single-species dynamics in a tropical multi-species context. In: Pauly D, Murphy GI (Eds). Theory and management of tropical fisheries. ICLARM Fishbyte 3, $13-14$. 
Pauly, D. (1983) Some simple methods for the assessment of tropical fish stock. FAO Fish. Tech. Pap. No. 234. p. 52.

Pauly, D. (1986) On improving operation and use of the ELEFAN programmes. Part II. Improving the estimation of L4. Fishbyte 4, $18-20$.

Pauly, D. \& Munro, J.L. (1984) Once more, on the composition of growth in fish and in vertebrates. Fishbyte 2, p. 21.

Pope, K.L., Lochmann, S.E. \& Young, M.K. (2010) Methods for assessing fish populations. In: Hubert, Wayne A; Quist, Michael C., eds. Inland Fisheries Management in North America, 3rd edition. Bethesda, MD: American Fisheries Society, 325 - 351.

Ragheb, E. (2016) Reproductive biology of Catfish Chrysichthys auratus, Geoffroy SaintHilaire, 1809, (Family: Bagridae) from Damietta branch of the River Nile, Egypt. Egyptian Journal of Aquatic Research 42, $349-356$

Sparre, P. \& Venema, S.C. (1998) Introduction to tropical fish stock assessment. Part 1. Manual. FAO. Fisheries Technical Paper No. 1. 306 Rev 2. Rome FAO. p. 407.

Ssentongo, G.W. \& Larkin, P.A. (1973) Some Simple Methods of Estimating Mortality Rates of Exploited Fish Populations. Journal of the Fisheries Research Board of Canada 30, 695 $-698$

Udoh, J.P., Ukpatu, J.E. \& Udoidiong, O.M. (2015) Population dynamics of Chrysichthys nigrodigitatus (Lacepede, 1803) in the Lower Cross River, Nigeria. Croatian Journal of Fisheries 73, 103 - 114.

Uneke, B.I. (2018) Stock Assessment of Chrysichthys nigrodigitatus in the Mid Cross River Flood System, South Eastern Nigeria: Implications for Fishery Management and Policy. American Journal of Environmental Policy and Management 4, 32 - 39 .

\section{Appendix}

TABLE 3

Monthly recruitment value of Chrysichthys nigrodigitatus in Ikere-gorge, Iseyin, Oyo State, Nigeria

\begin{tabular}{lr} 
Months & Recruitment values \\
\hline January & 3.39 \\
February & 3.62 \\
March & 10.86 \\
April & 9.46 \\
May & 15.81 \\
June & 12.33 \\
July & 5.57 \\
August & 6.52 \\
September & 22.62 \\
October & 9.74 \\
November & 0.1 \\
December & 0 \\
\hline
\end{tabular}

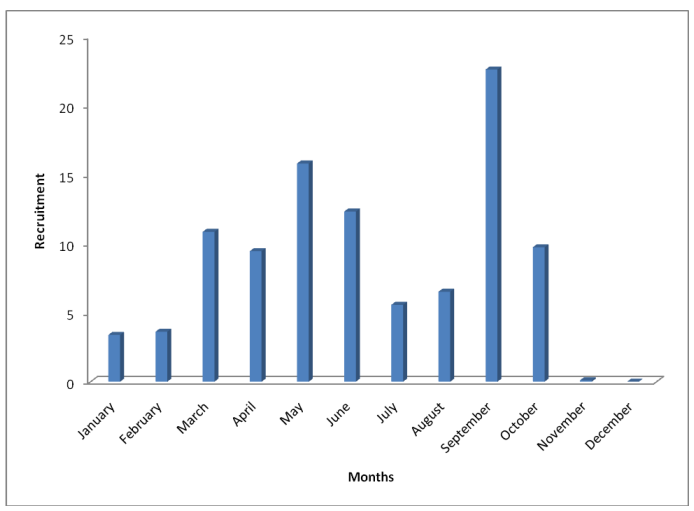

Fig. 6: Recruitment pattern of Chrysichthys nigrodigitatus in Ikere-gorge, Iseyin, Oyo State, Nigeria 